\title{
Evaluasi Beberapa Tolok Ukur Vigor untuk Pendugaan Perpanjangan Masa Edar Benih Padi (Oryza sativa L.)
}

\author{
Evaluation of Vigor From Several Variable to Estimate Relabelling Extension of \\ Rice Seeds (Oryza sativa L.)
}

\section{Lilis Yati Febriani dan Eny Widajati*}

Departemen Agronomi dan Hortikultura, Fakultas Pertanian, Institut Pertanian Bogor (Bogor Agricultural University), Jl. Meranti, Kampus IPB Darmaga, Bogor 16680, Indonesia Telp.\&Faks.62-251-8629353 e-mail agronipb@indo.net.id *Penulis untuk korespondensi: eny_widajati@yahoo.co.id

Disetujui : 14 November 2015 / Published online 12 Desember 2015

\begin{abstract}
The purpose of this research was to obtain the effective several variable of seed viability to determine relabelling of rice seeds. The research was conducted in the Seed Science and Technology Laboratory, Department of Agronomy and Horticulture, Faculty of Agriculture, Bogor Agricultural University and Indonesian Center for Seed Testing and Quality of Food Crops and Horticulture Research and Development, Cimanggis, Depok from July 2011 to October 2011. The design which used in this experiment is complete randomize block design with two factors. The first factor is seed lot and the second factor is storabilty period. The factor of lot consisting of var. Ciherang with expired date by 15 June 2011 (lot A), var. Inpari 10 Laeya expired date by 10 July 2011(lot B), var. Situ Bagendit expired date by 21 July 2011(lot C). The second factor is storabilty period consisting of 0, 2, 4, 6, 8, 10 and 12 week. Variable that has a effective to estimate storeability period for rice seed is delta value. This research show lot A reaches the end of Period II and entered to Period III of six weeks storage period. Lot B and Lot C anomalies reached a point, which is the maximum delta value at two weeks after the storage period. In the research, lot $B$ and lot $C$ can only be an relabelling to two week storage period.
\end{abstract}

Keywords: seed lot, seed storability, store period

\section{ABSTRAK}

Tujuan penelitian adalah untuk memperoleh beberapa tolok ukur vigor benih yang paling efektif untuk pendugaan perpanjangan masa edar benih padi. Penelitian ini dilakukan di Laboratorium Ilmu dan Teknologi Benih, Institut Pertanian Bogor dan Balai Besar Pengembangan Pengujian Mutu Benih Tanaman Pangan Hortikultura, Cimanggis, Depok dari bulan Juli 2011 sampai Oktober 2011. Rancangan yang digunakan dalam penelitian adalah rancangan acak lengkap dengan dua faktor. Faktor pertama adalah lot benih dan faktor kedua adalah periode simpan. Faktor lot benih terdiri atas var. Ciherang dengan tanggal kadaluarsa 15 Juni 2011 (Lot A), var. Inpari 10 Laeya dengan tanggal kadaluarsa 10 Juli 2011 (Lot B), var. Situ Bagendit dengan tanggal kadaluarsa 21 Juli 2011 (Lot C). Faktor kedua adalah periode simpan terdiri atas 0, 2, 4, 6, 8, 10 dan 12 minggu. Variabel yang efektif untuk menduga masa simpan benih padi adalah nilai delta. Penelitian ini menunjukkan Lot A mencapai akhir Periode II dan memasuki Periode III dari enam minggu periode penyimpanan. Lot $B$ dan Lot $C$ mencapai titik anomali, dengan nilai delta maksimum pada dua minggu setelah periode penyimpanan. Lot $B$ dan Lot $C$ pada penelitian ini hanya bisa dilakukan perpanjangan masa edar sampai periode simpan 2 minggu.

Kata kunci: daya simpan benih, lot benih, periode simpan 


\section{PENDAHULUAN}

Padi merupakan salah satu tanaman budidaya terpenting dalam peradaban. Produksi padi dunia menempati urutan ketiga dari serealia, setelah jagung dan gandum. Berdasarkan data BPS (2011), produksi padi mengalami peningkatan dari tahun 2009. Produksi padi meningkat dari 64398890 ton di tahun 2009 menjadi 66469394 ton untuk tahun 2010.

Menurut data dari Dirjen TP (2007), kebutuhan benih padi potensial dari tahun 2002 sampai tahun 2006 terus mengalami peningkatan. Kebutuhan benih unggul padi nasional mencapai 320000 ton (Deptan, 2008). Tahun 2011 subsektor tanaman pangan membutuhkan benih padi sebanyak 349000 ton, sedangkan ketersediaan benih padi baru mencukupi setengah dari kebutuhan total (Lazarde, 2011). Kurangnya produksi benih untuk kebutuhan pertanaman mendorong perlunya pengujian dan pelabelan ulang untuk benih yang sudah habis masa edarnya.

Berdasarkan Peraturan Dirjen TP Nomor: 01/Kpts/HK.310/C/1/2009 tentang Persyaratan dan Tata Cara Sertifikasi Benih Bina Tanaman Pangan dinyatakan bahwa "Benih bersertifikat yang telah mendekati atau habis masa edarnya, apabila akan diedarkan kembali harus dilakukan pengujian dan pelabelan ulang". Pengujian ulang biasanya dilakukan oleh lembaga sertifikasi yang meliputi pengujian rutin berupa pengujian daya berkecambah. Pada kenyataannya kondisi penanama di lapang lebih sering tidak se-optimum kondisi di laboratorium, sehinga lot benih yang mempunyai persentase daya berkecambah tinggi dapat memiliki nilai pemunculan kecambah (field emergency) yang rendah di lapang.

Vigor benih menurun lebih cepat dibandingkan viabilitas. Menurut hasil penelitian Ismattullah (2003) mengenai penyimpanan, vigor benih kedelai varietas Wilis lebih cepat menurun dibandingkan viabilitas potensial benihnya. Pada tolok ukur kecepatan tumbuh, benih kedelai lebih cepat menurun dibandingkan daya berkecambahnya. Kecepatan tumbuh benih kedelai mulai mengalami kemunduran pada periode simpan 4 bulan. Sedangkan pada tolok ukur daya berkecambah, benih kedelai baru mengalami kemunduran pada periode simpan 5 bulan. Penelitian Soejadi et al (2001) mengemukakan bahwa penurunan tajam daya berkecambah beberapa varietas benih padi terjadi pada periode simpan 16 minggu, sedangkan penurunan tajam vigor benih terjadi pada periode simpan 12 minggu.
Berdasarkan beberapa hasil penelitian tersebut, terlihat bahwa beberapa tolok ukur vigor benih dapat mendeteksi penurunan viabilitas benih lebih dini dibanding viabilitas potensialnya (DB). Penelitian akan mempelajari tolok ukur yang dapat digunakan untuk mendeteksi kemunduran lebih dini dan dapat digunakan untuk pendugaan perpanjangan masa edar benih padi. Tujuannya untuk menguji beberapa tolok ukur vigor benih yang paling efektif untuk pendugaan perpanjangan masa edar benih padi (Oryza sativa L.).

\section{BAHAN DAN METODE}

Penelitian dilaksanakan dari bulan Juni sampai dengan Oktober 2011 di Laboratorium Ilmu dan Teknologi Benih, Institut Pertanian Bogor, dan di Balai Besar Pengembangan Pengujian Mutu Benih Tanaman Pangan Hortikultura, Cimanggis, Depok. Terdapat tiga lot benih padi yang digunakan pada penelitian, yaitu : Lot A varietas Ciherang dengan tanggal kadaluarsa 15 Juni 2011, yang memiliki DB 94.7\%; Lot B varietas Inpari 10 Laeya dengan tanggal kadaluarsa 10 Juli 2011, yang memiliki DB 90\%; Lot C varietas Situ Bagendit dengan tanggal kadaluarsa 21 Juli 2011, yang memiliki DB $88 \%$. Ketiga lot benih tersebut diperoleh dari Balai Besar Pengembangan Pengujian Mutu Benih Tanaman Pangan Hortikultura, Cimanggis, Depok. Alat yang digunakan yaitu alat untuk mengukur viabilitas dan vigor benih serta peralatan untuk mengukur kadar air (oven $132{ }^{\circ} \mathrm{C}$, timbangan analitik, cawan dan desikator). Rancangan percobaan yang digunakan adalah Rancangan Acak Lengkap (RAL) dengan dua faktor. Faktor pertama yaitu lot dan faktor kedua periode simpan, pada faktor pertama berupa lot, digunakan 3 lot benih padi. Setiap lot benih diulang sebanyak tiga ulangan. Pengolahan data dilakukan dengan menggunakan uji F. Apabila menunjukkan pengaruh nyata, maka pengujian akan dilanjutkan dengan uji DMRT pada taraf $5 \%$.

Percobaan dilakukan pada 3 lot benih padi. Masing-masing lot dikemas menggunakan plastik bening yang telah disiapkan untuk 7 periode penyimpanan yaitu $0,2,4,6,8,10$ dan 12 minggu penyimpanan. Minggu ke 0 dimulai pada tanggal kadaluarsalot benih tersebut. Benih yang telah dikemas kemudian disimpan di suhu kamar $\left(\mathrm{RH}=80-90 \%\right.$ dan $\left.\mathrm{t}=27-31{ }^{\circ} \mathrm{C}\right)$. Penanaman benih dilakukan setiap 2 minggu sekali, yang dimulai dari minggu ke 0 . Metode penanaman benih menggunakan metode Uji Kertas Digulung didirikan dilapisi Plastik (UKDdp). Media yang 
digunakan berupa kertas stensil. Setiap ulangan terdiri dari 50 butir benih padi untuk $\mathrm{K}_{\mathrm{CT}}$, IV dan DB, serta 25 butir benih padi untuk BKKN. Parameter yang diamati di Laboratorium meliputi vigor dengan tolok ukur indeks vigor, nilai delta, kecepatan tumbuh dan viabilitas potensial dengan tolok ukur daya berkecambah dan bobot kering kecambah normal serta pengamatan kadar air benih.

\section{HASIL DAN PEMBAHASAN}

Semakin lama benih disimpan, maka secara alami benih akan mengalami deteriorasi. Viabilitas benih yang disimpan akan berangsurangsur menurun karena adanya kemunduran. Pengaruh lot benih terhadap tolok ukur vigor dan viabilitas benih dapat dilihat pada Tabel 1 . Penurunan vigor dan viabilitas benih untuk setiap periode simpan dapat dilihat pada Tabel 2.

Tabel 1 memperlihatkan bahwa Lot benih A memiliki viabilitas yang paling tinggi dibandingkan lot benih $\mathrm{B}$ dan lot benih $\mathrm{C}$. Tingginya nilai daya berkecambah untuk lot benih A didukung oleh tingginya nilai bobot kering kecambah normal, indeks vigor dan juga kecepatan tumbuh. Hal ini menandakan lot benih A memiliki laju kemunduran benih yang lambat dibandingkan lot benih $\mathrm{B}$ dan lot benih $\mathrm{C}$.

Tabel 1. Pengaruh lot terhadap tolok ukur indeks vigor (IV), daya berkecambah (DB), kecepatan tumbuh $\left(\mathrm{K}_{\mathrm{CT}}\right)$, bobot kering kecambah normal (BKKN)

\begin{tabular}{lccc}
\hline & \multicolumn{4}{c}{$\begin{array}{c}\text { Lot benih /Kadaluarsa } \\
\text { T(Tahun 2011) }\end{array}$} \\
\cline { 2 - 4 } Tolok Ukur & $\mathrm{A}$ & $\mathrm{B}$ & $\mathrm{C}$ \\
& (15 Juni) & (10 Juli) & (21 Juli) \\
\hline Indeks Vigor & $70.09 \mathrm{a}$ & $36.09 \mathrm{~b}$ & $25.42 \mathrm{c}$ \\
Daya Berkecambah & $89.52 \mathrm{a}$ & $72.48 \mathrm{~b}$ & $77.33 \mathrm{a}$ \\
Kecepatan Tumbuh & $18.27 \mathrm{a}$ & $14.89 \mathrm{~b}$ & $15.22 \mathrm{~b}$ \\
Bobot Kering & $(0.12 \mathrm{a})$ & $(0.08)$ & $(0.88)$ \\
Kecambah Normal & $0.79 \mathrm{a}$ & $0.77 \mathrm{~b}$ & $0.76 \mathrm{~b}$ \\
\hline Keterangan: Angka yang diikuti dengan huruf yang sama \\
pada baris yang sama tidak berbeda nyata pada \\
taraf 5\%. Angka dalam kurung merupakan data \\
asli
\end{tabular}

Indeks vigor adalah pembanding antara jumlah kecambah normal pada hitungan pertama dengan jumlah seluruh benih yang ditanam. Kolasinka et al. (2000) menyatakan bahwa persentase kecambah normal pada pengamatan pertama berhubungan erat dengan kemampuan benih berkecambah di lapang dibandingkan dengan persentase kecambah pada akhir pengamatan. Dengan demikian pengujian indeks vigor lebih peka dan dapat mencerminkan atau menginformasikan secara akurat potensi tumbuh dilapang dibandingkan dengan pengujian daya berkecambah.

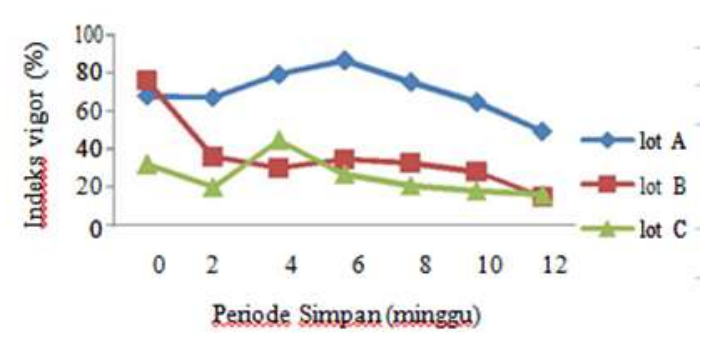

Gambar 1. Pengaruh periode simpan terhadap indeks vigor

Lot benih B memiliki nilai indeks vigor dan bobot kering kecambah normal yang lebih tinggi dibandingkan lot benih $\mathrm{C}$ (Gambar 1). Tingginya nilai indeks vigor untk lot benih $\mathrm{B}$ mengindikasikan bahwa lot benih $\mathrm{B}$ memiliki potensi tumbuh di lapang yang lebih tinggi dibandingkan lot benih C. Pengujian vigor umum digunakan untuk mengukur kemunduran benih. Indeks vigor dapat memonitor kondisi membran sebenarnya, perkecambahan yang rendah mengindikasikan terjadinya kerusakan membran pada benih yang telah melewati masa simpan.

Bobot kering kecambah tertinggi dimiliki oleh lot benih A (Tabel 1). Tingginya vigor untuk lot benih A menyebabkan reaksi-reaksi yang terjadi selama metabolisme benih tidak terhambat oleh respirasi dan tetap tersedia energi untuk pertumbuhan kecambah sehingga kecambah dapat tumbuh dan berkembang secara normal.

Tabel 1 memperlihatkan bahwa lot benih A memiliki nilai daya berkecambah yang lebih tinggi dibandingkan lot benih $\mathrm{B}$ dan lot benih $\mathrm{C}$. Lot benih B memiliki nilai daya berkecambah yang paling rendah dibandingkan lot benih $\mathrm{C}$. Rendahnya nilai viabilitas benih terlihat juga dari penurunan kecepatan tumbuh yang semakin cepat. Gambar 2 terlihat bahwa lot benih A mampu mempertahankan viabilitasnya mencapai diatas 80\% pada akhir periode simpan. Lot benih benih B dan Lot benih benih $\mathrm{C}$ sudah mengalami penurunan viabilitas dibawah $80 \%$ ketika memasuki periode simpan 4 minggu.

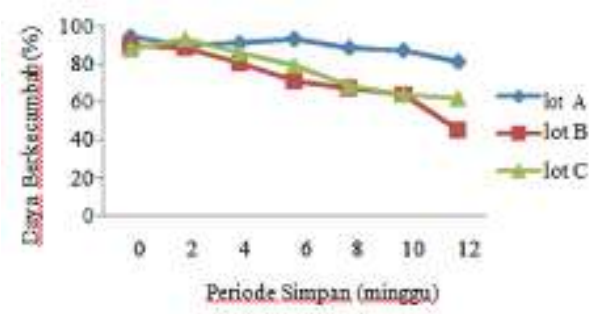

Gambar 2. Pengaruh periode simpan terhadap daya berkecambah 
Tingginya nilai viabilitas didukung dengan tingginya nilai kecepatan tumbuh. Lot benih yang memiliki viabilitas yang tinggi menunjukkan penurunan yang lambat (Gambar 3). Semakin menurunnya nilai kecepatan tumbuh mengindikasikan bahwa vigor benih telah mengalami penurunan. Lot benih A memiliki kecepatan tumbuh yang lebih tinggi, terlihat dari grafik yang lebih landai dibandingkan lot benih $\mathrm{B}$ dan lot benih $\mathrm{C}$. Lot benih A memiliki nilai kecepatan tumbuh tertinggi dibandingkan dengan lot benih B dan C, yaitu sebesar $18.27 \%$ etmal $^{-1}$ pada Tabel 1. Lot benih B memiliki nilai kecepatan tumbuh yang paling rendah dibandingkan lot benih C yaitu sebesar $14.89 \%$ etmal $^{-1}$.

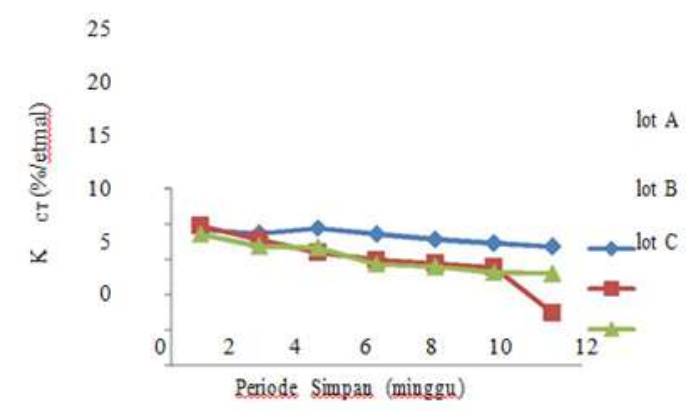

Gambar 3. Pengaruh periode simpan terhadap kecepatan tumbuh

Berdasarkan semua tolok ukur yang diamati, lot benih A memiliki nilai viabilitas dan vigor yang lebih tinggi dibandingkan lot benih B dan lot benih $\mathrm{C}$. Hal ini diduga berhubungan dengan viabilitas lot benih selama penyimpanan. Salah satu faktornya yaitu kadar air benih. Lot benih A memiliki kadar air awal yang rendah dibandingkan lot benih $\mathrm{B}$ dan lot benih $\mathrm{C}$ (Tabel 5). Rendahnya kadar air awal lot benih benih akan berpengaruh terhadap kadar air benih dalam penyimpanan. Kadar air selama penyimpanan yang tetap rendah, membuat laju metabolisme menjadi lambat yang berakibat pada lambatnya laju deteriorasi.

Faktor internal lainnya yaitu viabilitas awal benih, diduga lot benih A merupakan lot benih benih hasil panen musim kemarau, sehingga masak fisiologis terjadi dengan baik. Masak fisiologis yang tepat menggambarkan viabilitas optimal benih. Benih yang memiliki viabilitas awal tinggi akan memiliki daya simpan yang lebih lama daripada benih dengan viabilitas awal rendah.

Tabel 2 menunjukkan bahwa terjadi penurunan viabilitas yang nyata pada periode simpan 2 minggu berdasarkan tolok ukur indeks vigor. Jika dilihat berdasarkan tolok ukur daya berkecambah dan bobot kering kecambah penurunan viabilitas secara nyata baru terlihat pada periode simpan 8 minggu. Berdasarkan kecepatan tumbuh penurunan viabilitas secara nyata terjadi pada 6 minggu periode simpan.

Tabel 2. Pengaruh periode simpan terhadap tolok ukur vigor, viabilitas potensial dan kadar air

\begin{tabular}{|c|c|c|c|c|c|c|c|}
\hline \multirow{2}{*}{ Tolok ukur } & \multicolumn{7}{|c|}{ Periode Simpan } \\
\hline & 0 & 2 & 4 & 6 & 8 & 10 & 12 \\
\hline \multirow{3}{*}{ IV } & 58.67 & 41.11 & 51.56 & 49.33 & 42.89 & 36.89 & 26.67 \\
\hline & $\mathrm{a}$ & bc & $a b$ & $a b$ & $\mathrm{bc}$ & $\mathrm{cd}$ & d \\
\hline & $(32.22)$ & $(49.56)$ & $(34.44)$ & $(32.00)$ & $(32.00)$ & $(34.89)$ & $(36.22)$ \\
\hline \multirow[t]{2}{*}{ Delta } & 5.44 & 6.86 & 5.67 & 5.32 & 5.52 & 5.84 & 5.94 \\
\hline & $\mathrm{b}$ & $\mathrm{a}$ & $\mathrm{b}$ & $\mathrm{b}$ & $\mathrm{b}$ & $\mathrm{b}$ & $\mathrm{b}$ \\
\hline \multirow{2}{*}{ KCT } & 19.16 & 17.77 & 17.35 & 15.95 & 15.42 & 14.79 & 12.43 \\
\hline & $\mathrm{a}$ & $\mathrm{ab}$ & $a b$ & $\mathrm{~b}$ & $\mathrm{bc}$ & $\mathrm{bc}$ & $\mathrm{c}$ \\
\hline \multirow{3}{*}{ DB } & 90.89 & 90.67 & 86.00 & 81.33 & 74.89 & 71.78 & 62.89 \\
\hline & $\mathrm{a}$ & $\mathrm{a}$ & $\mathrm{ab}$ & $a b c$ & bcd & $\mathrm{cd}$ & d \\
\hline & $(0.14)$ & $(0.14)$ & $(0.11)$ & $(0.10)$ & $(0.09)$ & $(0.05)$ & $(0.04)$ \\
\hline \multirow[t]{2}{*}{ BKKN } & 0.80 & 0.80 & 0.78 & 0.78 & 0.77 & 0.74 & 0.73 \\
\hline & $\mathrm{a}$ & $\mathrm{a}$ & $a b$ & $\mathrm{~b}$ & $\mathrm{~b}$ & $\mathrm{c}$ & $\mathrm{c}$ \\
\hline \multirow{2}{*}{ KA } & 13.01 & 12.96 & 13.31 & 12.88 & 13.07 & 12.95 & 13.89 \\
\hline & $\mathrm{b}$ & $\mathrm{b}$ & $a b$ & $\mathrm{~b}$ & $\mathrm{~b}$ & $\mathrm{~b}$ & $\mathrm{a}$ \\
\hline
\end{tabular}

Keterangan: Angka yang diikuti dengan huruf yang sama tidak berbeda nyata pada taraf 5\%.Angka dalam kurung merupakan data asli sebelum ditransformasi

Hal ini menunjukkan bahwa tolok ukur vigor lebih dini dalam mendeteksi kemunduran benih dibandingkan tolok ukur viabilitas potensial. Indeks vigor mampu mendeteksi penurunan viabilitas lebih dini dibandingkan tolok ukur lainnya. Hal ini sesuai dengan konsep
Steinbauer-Sadjad bahwa vigor benih lebih cepat mengalami penurunan dibandingkan viabilitas potensialnya (DB) (Sadjad, 1993). 


\section{Pengaruh Interaksi Lot Benih dan Periode Simpan terhadap Nilai Delta}

Nilai Delta merupakan selisih antara daya berkecambah dengan indeks vigor. Benih yang telah memasuki masa kadaluarsa akan mengalami penurunan viabilitas, baik viabilitas potensial maupun vigor. Awal Periode III dicirikan oleh meningkatnya nilai delta. Nilai delta tersebut akan meningkat dan mencapai maksimum pada titik tertentu, kemudian menurun kembali dan mencapai titik nol menjelang akhir periode kehidupan benih. Titik dengan nilai delta maksimum pada Periode III disebut titik anomali. Benih sudah tidak dapat berfungsi lagi sebagai benih pada titik anomali tersebut (Sadjad, 1994). Saat tersebut benih juga sudah tidak boleh diedarkan kembali.

Tabel 3. Pengaruh interaksi lot benih dan periode simpan terhadap nilai delta

\begin{tabular}{|c|c|c|c|c|c|c|c|}
\hline \multirow{2}{*}{ Lot Benih } & \multicolumn{7}{|c|}{ Periode Simpan } \\
\hline & 0 & 2 & 4 & 6 & 8 & 10 & 12 \\
\hline & $(26.67)$ & $(22.67)$ & $(12.00)$ & $(6.67)$ & (13.33) & $(22.67)$ & (32) \\
\hline & 5.19 & 4.79 & 3.50 & 2.58 & 3.69 & 4.76 & 5.68 \\
\hline \multirow[t]{3}{*}{ A } & $\mathrm{Ba}$ & $\mathrm{Bab}$ & $\mathrm{Bbc}$ & $\mathrm{Cc}$ & $\mathrm{Cbc}$ & $\mathrm{Bab}$ & $\mathrm{Aa}$ \\
\hline & $(14.00)$ & $(52.67)$ & $(50.00)$ & $(36.67)$ & $(34.67)$ & $(36.00)$ & $(30.67)$ \\
\hline & 3.68 & 7.20 & 7.10 & 6.09 & 5.91 & 5.95 & 5.37 \\
\hline \multirow[t]{3}{*}{ B } & $\mathrm{Bb}$ & $\mathrm{Aa}$ & $\mathrm{Aa}$ & $\mathrm{Bab}$ & $\mathrm{Bab}$ & $\mathrm{ABab}$ & Aab \\
\hline & $(56)$ & $(73.33)$ & $(41.33)$ & $(52.67)$ & (48) & $(46)$ & $(46)$ \\
\hline & 7.46 & 8.59 & 6.44 & 7.23 & 6.96 & 6.80 & 6.79 \\
\hline $\mathrm{C}$ & $\mathrm{Ab}$ & $\mathrm{Aa}$ & $\mathrm{Ab}$ & $\mathrm{Ab}$ & $\mathrm{Ab}$ & $\mathrm{Ab}$ & $\mathrm{Ab}$ \\
\hline
\end{tabular}

Keterangan: Angka-angka yang diikuti oleh huruf kapital yang sama pada kolom yang sama, dan angka-angka yang diikuti oleh huruf kecil yang sama pada baris yang sama menunjukkan tidak berbeda nyata pada uji DMRT 5\%. Angka dalam kurung merupakan data asli

Lot benih A mengalami peningkatan nilai delta pada 6 minggu periode simpan (Tabel 3 dan Gambar 4). Hal ini menunjukkan bahwa periode simpan 6 minggu merupakan titik akhir Periode II dan lot benih sudah masuk dalam Periode III. Peningkatan nilai delta terus terjadi sampai 12 minggu periode simpan, sehingga untuk lot benih A belum dapat diketahui titik anomalinya.

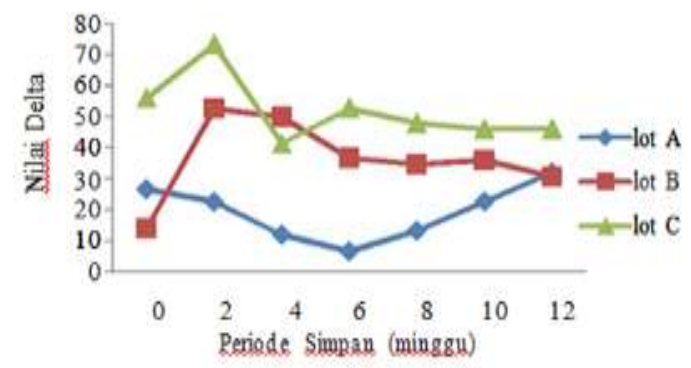

Gambar 4. Pengaruh periode simpan terhadap nilai delta

Lot benih B dan lot benih C mulai menunjukkan peningkatan nilai delta dari 0 minggu hingga 2 minggu periode simpan (Tabel 3 dan Gambar 4). Hal ini menunjukkan bahwa benih telah memasuki Periode III. Titik maksimum nilai delta dicapai pada minggu ke 2 periode simpan. Titik tersebut merupakan titik anomali untuk lot benih B dan lot benih C. Sehingga setelah periode simpan 2 minggu kedua lot benih tersebut sudah tidak bisa diperpanjang kembali masa edarnya.

Pengaruh Interaksi Lot Benih dan Periode

\section{Simpan Terhadap Kadar Air}

Tabel 4 memperlihatkan pengaruh lot benih dan periode simpan terhadap kadar air. Terlihat bahwa lot benih $\mathrm{B}$ dan $\mathrm{C}$ memiliki viabilitas yang sama dari awal penyimpanan hingga 12 minggu periode simpan (Gambar 5). Lot benih B dan lot benih $\mathrm{C}$ tidak menunjukkan adanya kenaikan dan penurunan kadar air secara nyata dari awal periode simpan hingga akhir periode simpan. Nilai kadar air yang tidak berbeda nyata selama 12 minggu periode simpan diduga berhubungan dengan sifat plastik polietilen yang digunakan sebagai bahan pengemas yang kedap terhadap air dan udara. Hal ini menyebabkan benih sedikit menyerap uap air dari lingkungan simpan selama periode simpan. Lot benih A baru mengalami peningkatan kadar air yang nyata pada periode simpan 8 minggu yaitu $13.63 \%$.

Lot benih A memiliki kadar air yang lebih rendah pada awal periode simpan yaitu sebesar $10.90 \%$ dan menunjukkan adanya perbedaan yang nyata dibandingkan lot benih $\mathrm{B}$ dan lot benih C (Tabel 4). Lot benih B dan lot benih $\mathrm{C}$ memiliki kadar air yang tinggi pada awal periode simpan yaitu $13.93 \%$ dan $14.21 \%$. Tingginya nilai kadar air menyebabkan terjadinya penurunan viabilitas dan laju kemunduran benih semakin cepat. Hal ini terlihat dari rendahnya nilai daya berkecambah dan kecepatan tumbuh untuk kedua lot benih 
dibandingkan dengan lot benih $\mathrm{A}$.

Tabel 4. Pengaruh interaksi lot benih dan periode simpan terhadap kadar air

\begin{tabular}{llllllll}
\hline & \multicolumn{7}{c}{ Periode simpan } \\
\cline { 2 - 7 } Lot Benih & 0 & 2 & 4 & 6 & 8 & 10 & 12 \\
\hline
\end{tabular}

\begin{tabular}{|c|c|c|}
\hline \multirow[t]{2}{*}{ A } & 10.9011 .0712 .0511 .20 & 11.2811 .2613 .63 \\
\hline & $\mathrm{Bb} \quad \mathrm{Bb} \quad \mathrm{Ab} \quad \mathrm{Bb}$ & $\mathrm{Bb} \quad \mathrm{Bb} \mathrm{Aa}$ \\
\hline \multirow{2}{*}{ B } & 13.9313 .9713 .9713 .64 & $13.81 \quad 13.6413 .74$ \\
\hline & $\mathrm{Aa}$ & Aa Aa \\
\hline$C$ & 14.2113 .8313 .9013 .82 & 14.1013 .9514 .31 \\
\hline$c$ & $\mathrm{Aa} \mathrm{Aa} \mathrm{Aa} \mathrm{Aa}$ & $\mathrm{Aa} \mathrm{Aa}$ \\
\hline
\end{tabular}

Keterangan: Angka-angka yang diikuti oleh huruf kapital yang sama pada kolom yang sama, dan angkaangka yang diikuti oleh huruf kecil yang sama pada baris yang sama menunjukkan tidak berbeda nyata pada uji DMRT 5\%. Angka dalam kurung merupakan data asli

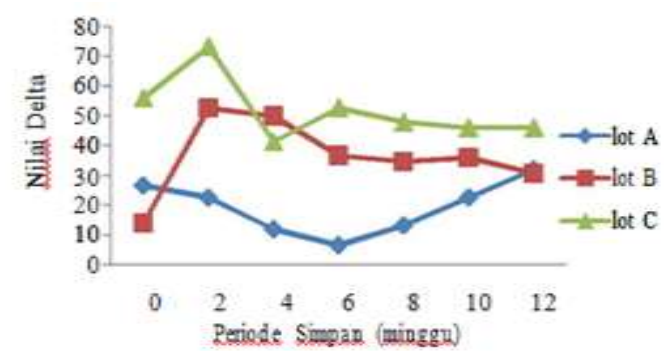

Gambar 5. Pengaruh periode simpan terhadap kadar air beberapa lot benih

Menurut Sutopo (2004) benih yang disimpan dengan kadar air yang lebih tinggi akan meningkatkan kegiatan enzim yang dapat mempercepat proses respirasi. Justice dan Bass (2002) menambahkan, semakin lama proses respirasi, semakin banyak cadangan makanan yang digunakan. Perombakan cadangan makanan benih menyebabkan proses metabolisme yang dapat menurunkan viabilitas benih.

Kadar air merupakan faktor penting agar viabilitas benih dapat dipertahankan dalam penyimpanan. Justic dan Bass (2002) menyatakan bahwa kadar air benih akan selalu mengadakan keseimbangan dengan kelembaban nisbi udara sekitarnya. Menurut Harington (1972), setiap kenaikan kadar air benih sebesar $1 \%$ akan memperpendek umur benih menjadi setengahnya.

\section{KESIMPULAN}

Indeks Vigor, Nilai delta dan Kecepatan Tumbuh dapat mendeteksi laju kemunduran lebih dini dibandingkan Daya Berkecambah dan Bobot Kering Kecambah Normal. Nilai delta merupakan tolok ukur yang paling baik untuk mendeteksi laju kemunduran dan dapat digunakan untuk menentukan perpanjangan masa edar benih. Lot benih A mencapai akhir periode II dan masuk periode III pada periode simpan 6 minggu dan perpanjangan masa edarnya lebih dari 12 minggu pada penelitian ini. Lot benih B dan lot benih C mencapai titik anomali dimana nilai delta maksimum pada 2 minggu setelah periode simpan. Pada lot yang diteliti untuk lot benih B dan lot benih $\mathrm{C}$ hanya bisa dilakukan perpanjangan masa edar sampai periode simpan 2 minggu.

Berdasarkan tolok ukur daya berkecambah, pada periode simpan 4 minggu lot benih A memiliki nilai daya berkecambah sebesar 91.3\%, lot benih B $80.67 \%$ dan lot benih C $86 \%$, tetapi berdasarkan nilai delta ketiga lot benih tersebut dapat dibedakan secara nyata dimana lot A memiliki nilai delta 32 , lot benih B dan C sudah menunjukkan peningkatan nilai delta secara nyata dengan nilai delta 52.67 dan 73.33 pada 2 minggu periode simpan.

\section{DAFTAR PUSTAKA}

[BPS] Badan Pusat Statistik. 2011. Data Tanaman Pangan [Internet]. [diunduh 2011 Nov 27]. Tersedia pada: http://www.bps.go.id.

[Deptan] Departemen Pertanian. 2008. Pelatihan untuk Fasilitator (TOT) Sekolah-sekolah Lapangan Penyilangan Benih [Internet]. [diunduh 2011 Nov 27]. Tersedia pada: http://api-indonesia.blogspot.com.

[Dirjen TP] Direktorat Jenderal Tanaman Pangan. 2007. Konsepsi Subsidi Benih. Jakarta (ID) : Direktorat Jenderal Tanaman Pangan.

Ismattullah. 2003. Studi penciri mutu benih kedelai (Glycine max (L) Merrill) varietas wilis selama penyimpanan [skripsi]. Bogor (ID): Institut Pertanian Bogor.

Justice, O.L., Bass, L.N. 2002. Prinsip dan Praktek Penyimpanan Benih. Roeli, R., penerjemah. Jakarta (ID): PT Raja Grafindo Persada. Terjemah dari: Principles and Seed Storage Practices.

Kolasinka, K., Szyrmer, J., Dul, S. 2000. Relationship between laboratory seed quality test and field emergence of common bean seed. Crop Sci. (40): 470475 . 
Lazarde, I. 2011. Swasembada Pangan Kekurangan Benih [Internet]. [diunduh 2011 Des 01]. Tersedia pada: http://www.republika.co.id.

Sadjad, S. 1993. Dari Benih Kepada Benih. Jakarta (ID): PT Gramedia Widiasarana Indonesia.
Sadjad, S. 1994. Kuantifikasi Metabolisme Benih. Jakarta (ID): PT Gramedia Widiasarana Indonesia.

Soejadi, U.S. Nugraha, Rasam. 2001. Evaluasi mutu benih beberapa genotipe padi selama penyimpanan. Jurnal Pertanian Penelitian Tanaman Pangan 20(3): 1723. 